ReVISTA de BIOLOGía TROPICAL

\title{
Epiphytes from a forest type transition zone in the Choco biogeographic region, Valle del Cauca, Colombia
}

\author{
Edier Soto-Medina, Viviana Londoño-Lemos \& David Díaz-Escandón \\ Grupo de Investigación Ecología y Diversidad Vegetal; Departamento de Biología, Facultad de Ciencias Naturales y \\ Exactas, Calle 13 \# 100-00, Universidad del Valle, Cali, Colombia; edier.soto@correounivalle.edu.co, \\ vlondon28@gmail.com, ddiazescandon@gmail.com
}

Received 28-X-2014. Corrected 10-VI-2015. Accepted 02-VII-2015.

\begin{abstract}
Tropical moist forests are ecosystems of high biodiversity and high endemism, like the Choco biogeographic ecoregion. Few studies have characterized this vegetation system, and less attention has been given to the epiphytes. The aim of this study, was to evaluate the diversity and composition of vascular and nonvascular epiphytes, in a transition zone between tropical moist forest and tropical dry forest in the Choco biogeographic region of Valle del Cauca, Colombia. For this study, the data were grouped into six zones along the Loboguerrero-Buenaventura road: Zone 1 was closest to the Pacific Ocean (tropical moist forest) and Zone 6 was closest to the subxerophytic enclave of The Dagua River (transition zone to tropical dry forest). The data also were grouped depending on exposure to light (microsites), and the sites were categorized as open, semiopen and closed. A total of 43 trees densely covered by epiphytes were sampled: non-vascular epiphytes were sampled up to $2 \mathrm{~m}$ high, while vascular epiphytes were sampled along the entire phorophyte. A total of $485 \mathrm{spec}-$ imens of non-vascular epiphytes belonging to 77 species of lichens, five of liverworts and eight of mosses were collected, for a total of 90 species. In addition, 5987 individuals belonging to 24 species of vascular epiphytes were found; Bromeliaceae (six species) was the richest in species, followed by Gesneriaceae, Orchidaceae and Polypodiaceae (each with four species). We found 25 new records of lichens for Colombia and 26 for the Choco biogeographic region; for vascular epiphytes, we found 11 new records for this same Choco region. The richness and diversity of nonvascular epiphytic communities were affected by the zone and the microsite in which the trees were located, while the vascular epiphytic communities, were affected by the zone along the road. Thus, the richness and diversity of the communities of nonvascular epiphytes were affected by both the forest type and the microsite where the trees were found, while communities of vascular epiphytes, were affected only by the forest type. Rev. Biol. Trop. 63 (4): 915-926. Epub 2015 December 01.
\end{abstract}

Key words: Choco biogeographic region, composition, diversity, microclimate factors, microsites, richness, vascular and nonvascular epiphytes.

Epiphytes are a group of specialized plants that spend much or all of their life on other plants, mainly trees and shrubs (Benzing, 1987; Gentry \& Dodson, 1987; Bartels \& Chen, 2012). Several groups of organisms have epiphytic species (algae, mosses, lichens and vascular plants) which also represent a substantial part of the forest biomass and carry out several functions such as the regulation of the water cycle through the fog, nitrogen fixation, habitat for animals, among others (Benzing, 1987; Gentry \& Dodson, 1987; Wolf, 1994; Bartels \&
Chen, 2012). Additionally, epiphytes form one of the most diverse groups in the Neotropics, mainly in the cloudy forests and rainy forests of the Northern Andes (Gentry \& Dodson, 1987; Wolf, 1994; Foster, 2001).

Tropical moist forests are ecosystems that accumulate high biodiversity and high endemism, especially in the Choco ecoregion. This is one of the most diverse regions of the planet with, about 9000 species of vascular plants, 200 mammals, 600 birds, 100 reptiles and 120 amphibians (Rangel, 2011; Ruiz-Dominguez \& 
Cabrera-Rodriguez, 2012). Despite its importance, this area has not been well explored, and there are large taxonomic, ecological and biogeographical gaps for almost all biological groups, and from where approximately 25 $\%$ of the biodiversity has not been explored (Rangel, 2011, Ruiz-Dominguez \& CabreraRodriguez, 2012). Moreover, this area has been endangered by an alarming logging rate, mining, illegal land acquisitions, illegal lumber extraction and illicit crops, in addition to road construction.

Epiphytes are particularly vulnerable to human disturbance and climate change because they have strict requirements of lighting conditions and moisture, being the nonvascular species the most sensitive to changes in microenvironmental conditions (McCune, Grace \& Urban, 2002; Cáceres, Lücking, \& Rambold, 2007; Rangel, 2011; Bartels \& Chen, 2012). Despite of the importance of epiphytes as indicators of human impact, few studies have been carried out on the taxonomy and ecology of this group in Colombia; research has been less focused on nonvascular epiphytes, and even fewer studies have been done that include all groups of epiphytes within an area. To understand the changes that epiphyte communities suffer because of disturbance, it is necessary to know their actual diversity in natural conditions and their diversity related to different levels of disturbance in the distinct Choco biogeographic ecosystems. This will guide new research that will help us to understand and follow the changes in epiphytic biodiversity due to anthropic disturbances and global warming. Thereby, the aim of this research project was to evaluate the composition and assemblage of vascular and nonvascular epiphytes along a road in a transition zone between tropical moist forest to tropical dry forest in the Choco biogeographic region.

\section{MATERIALS AND METHODS}

Study area: The samples were taken along the Loboguerrero-Buenaventura road, in the section Cisneros-Triana (ca. $3 \mathrm{~km}$ ), municipio of Buenaventura, department of Valle del Cauca, Colombia. The Chocó ecoregion area is over $320 \mathrm{~m}$ altitude, with an average temperature of $25.9{ }^{\circ} \mathrm{C}$ and an average precipitation of $2098.6 \mathrm{~mm}$ (IDEAM, 2014), which classifies it as Tropical moist forest in the Holdridge system (Holdridge, 1967). There is a transition from tropical moist forest (the area closest to the Pacific Ocean) to subxerophytic Dagua River enclave, which is indicated by changes in the plant communities along the transect.

Epiphyte sampling: A total of 43 phorophytes (tree) with a high coverage of epiphytes were chosen. For nonvascular epiphyte sampling, we measured $\left(\mathrm{cm}^{2}\right)$ all thalli located from the base of the trunk up to $2 \mathrm{~m}$ height, calculating coverage by species (McCune, 1990; Rosabal, Burgaz, \& de la Masa, 2010). The coverage was measured as the area covered by each thallus over the sampled trunk expressed as a percentage (Rosabal et al., 2010). In the case of vascular epiphytes, all individuals on the trees were counted, recording the number of individuals per species, understanding each individual as the smallest unit distinguishable. The samples were deposited in the CUVC Herbarium of the Universidad del Valle, in Cali, Colombia.

Data analysis: Richness, abundance and epiphytic coverage were estimated by tree, and the importance value index per family (IVIF) for vascular epiphytes according to Mori, Boom, Carvalho, \& dos Santos (1983) was calculated. The data were grouped into six zones along the route, with zone 1 closest to the Pacific ocean (tropical moist forest) and zone 6 closest to the subxerophytic enclave of the Dagua River (transition zone to tropical dry forest). Within each area six to seven trees were selected. Also, these zones were pooled depending on exposure to light (microsites) categorized as open (with direct input light, trees in open places), semi-open (intermediate input light, as forest edges) and closed (trees inside forest, separate from the road). 
Two-way ANOVA was used to compare the richness and abundance of epiphytes between zones and microsites in the Statistica software version 7.1 (StatSoft, 2005). To evaluate the relationship between nonvascular species richness, and bryophyte and lichen coverage, an edges (margins) EcoSim test (Gotelli \& Entsminger, 2002) was performed. Non Metric Multidimensional Scaling (NMS) was performed to as certain see clustering patterns between all trees and their relation to lichen and bryophyte coverage, diameter at breast height (DBH) and geographic coordinates, all performed in PC-ORD software version 4.0 (McCune \& Mefford, 1999). To measure these relationships, the Spearman correlation coefficient was calculated in the Statistica version 7.1 software (StatSoft, 2005). Additionally, a multi-response permutation procedure (MRPP) was performed with the Sørensen index in PC-ORD software version 4.0 (McCune \& Mefford, 1999) to compare lichen assemblages between zones and microsites.

\section{RESULTS}

Epiphyte diversity: A total of 485 samples of nonvascular epiphytes belonging to 77 species of lichens, five liverworts and eight mosses were collected ( 90 species). The dominant family among the lichens was Graphidaceae with 15 species, followed by Arthoniaceae (12) and Ramalinaceae (nine), while less dominant families were Caliciaceae, Lobariaceae and Pilocarpaceae (one each). This was the first record of Lobariaceae in the Choco Biogeographic region (under $320 \mathrm{~m}$ ). Twenty-five species are new records for Colombia and 26 for the Choco region (Fig. 1). We also report for the first time the genus Thecaria in Colombia. As for bryophytes, the dominant family was Calymperaceae (four species), while Daltoniaceae, Lejeuneaceae and Octoblepharaceae had the fewest representatives (one each). In addition, 5987 individuals belonging to 24 species of vascular epiphytes were recorded; the richest family was Bromeliaceae (six species), followed by Gesneriaceae, Orchidaceae and Polypodiaceae (four each). Eleven of these species are new records for the Choco biogeographic Valle del Cauca region.

The richness of nonvascular epiphytes was significantly higher in open sites (18 species on average) than in closed sites (eight) or semiopen ones (nine) (ANOVA, $p<0.001$ ). On the other hand, the coverage of bryophytes tended to be higher in closed microsites, while lichen coverage was higher in the semi-open sites, although the differences were not significant (ANOVA: $p=0.78, p=0.24$, respectively) (Table 1). The highest species richness was found in zone 3 and the lowest in zone 4.

Families with the highest IVIF were Bromeliaceae (190), Polypodiaceae (122), Gesneriaceae (82), and Orchidaceae (81). In terms of abundance and species richness of vascular epiphytes, there were no significant differences among zones (ANOVA: $p=0.91$ ), but there were among sites (ANOVA: $\mathrm{p}=0.031$ ); richness tended to be higher in closed microsites. The richness was similar among zones, but the abundance tended to be lower in zone 3 (90 individuals) and highest in zone 2 (125 individuals). The most abundant species were Guzmania rhonhofiana, Pleopeltis bombycina Harms (Maxon) AR Sm. and Campyloneurum phyllitidis (L.) C. Presl (with 3627, 378 and 352 individuals, respectively), while Tillandsia usneoides (L.) L. and Vriesea gladioliflora $(\mathrm{H}$. Wendl.) Antoine resulted less abundant, with one record.

The nonvascular species with the highest coverage were Plagiochila sp.1 (27373 $\mathrm{cm}^{2}$ ), Herpothallon japonicum (Zahlbr.) G. Thor $\left(25454 \mathrm{~cm}^{2}\right)$, Dichosporidium nigrocinctum $\left(33852 \mathrm{~cm}^{2}\right)$ and Herpothallon minimum $\left(27410 \mathrm{~cm}^{2}\right)$, while Dirinaria picta $\left(2 \mathrm{~cm}^{2}\right)$, Dictyonema obscuratum Lücking, Spielmann \& Marcelli $\left(1 \mathrm{~cm}^{2}\right)$ and Laurera megasperma $\left(3 \mathrm{~cm}^{2}\right)$ were the least abundant. A $48.4 \%$ of the species were rare $(16.5 \%)$ to very rare $(31.9 \%)$, while only five species were fairly common (more than 20 trees, Plagiochila sp.1, Dichosporidium nigrocinctum, G. glaucescens, H. minimum and Herpothallon roseocinctum). Thus, the general pattern was that the 

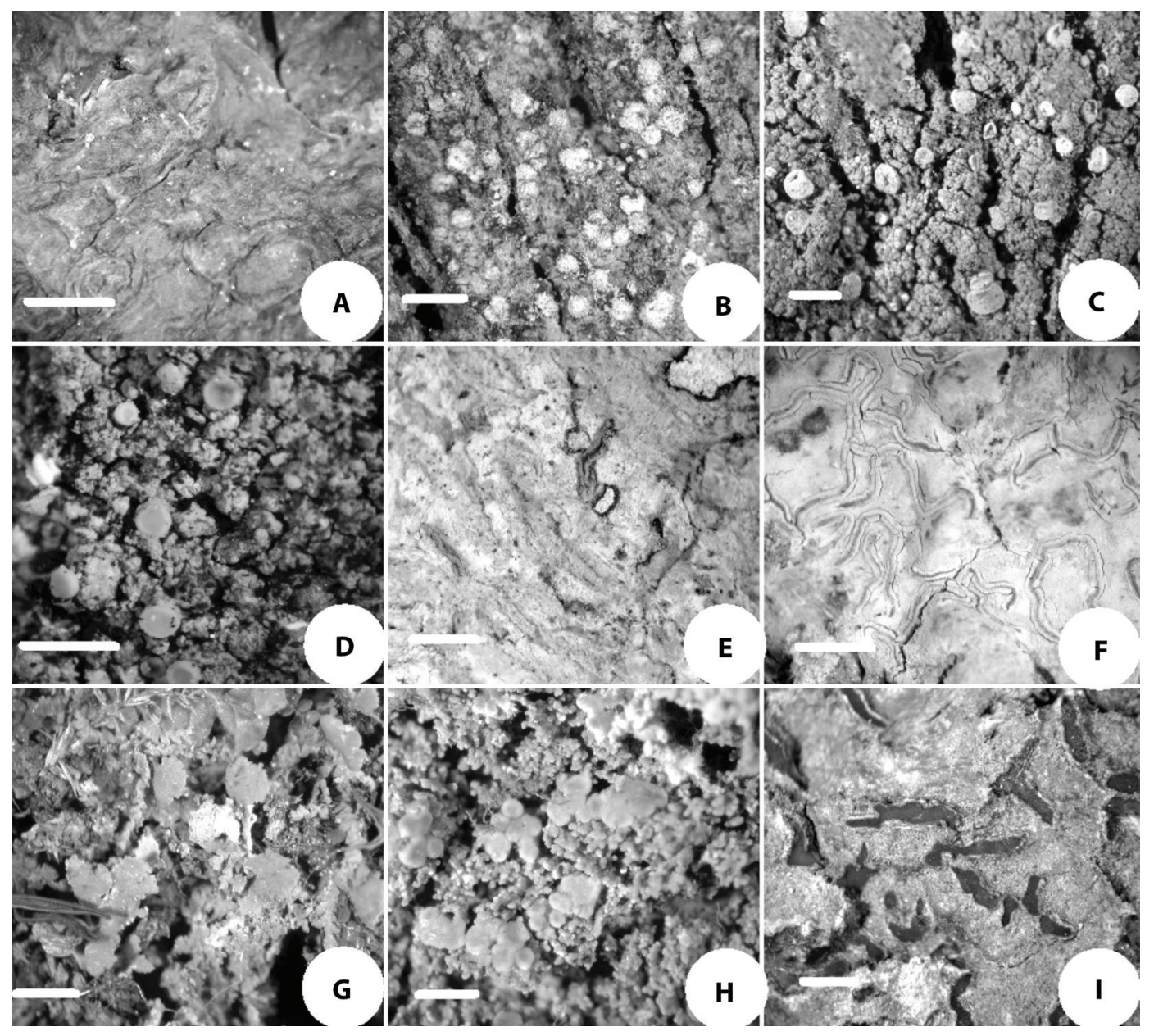

Fig. 1. New lichens records for Colombia. (A) Anthracothecium prasinum (Eschw.) R. C. Harris. (B) Arthonia aff. cinnabarina. (C) Calopadia editae Vezda ex Chaves \& Lücking. (D) Coenogonium pineti (Ach.) Lücking \& Lumbsch. (E) Graphis ferruginea Vain. (F) Graphis glaucescens Fée. (G) Phyllopsora labriformis Timdal. (H) P. chlorophaea (Müll. Arg.) Zahlbr. (I) Thecaria montagnei (Bosch) Staiger. White bar= $1 \mathrm{~mm}$.

Fig. 1. Nuevos registros de líquenes para Colombia. (A) Anthracothecium prasinum (Eschw.) R. C. Harris. (B) Arthonia aff. cinnabarina. (C) Calopadia editae Vezda ex Chaves \& Lücking. (D) Coenogonium pineti (Ach.) Lücking \& Lumbsch. (E) Graphis ferruginea Vain. (F) Graphis glaucescens Fée. (G) Phyllopsora labriformis Timdal. (H) P. chlorophaea (Müll. Arg.) Zahlbr. (I) Thecaria montagnei (Bosch) Staiger. White barra=1mm.

most abundant species were the most frequent among the trees $\left(\mathrm{r}_{\mathrm{s}}=0.75, \mathrm{p}<0.001\right)$.

When the richness of nonvascular epiphytes vs. the abundance of bryophytes and lichens was analyzed, it showed that trees with high bryophyte and lichen coverage tended to have lower nonvascular species richness (edges test, $\mathrm{p}=0.88$ ) (Fig. 2).

We also found that trees with high bryophyte coverage tended to have lower lichen coverage (edges test) (Fig. 2). This indicates that it is unlikely that trees with high coverage of lichens or bryophytes have high nonvascular diversity, while is likely that trees with low coverage of lichens and bryophytes have high diversity.

Species composition: The closed and semi-open microsites had a similar species assemblage and were different from the open 
TABLE 1

Richness, abundance and coverage of vascular and nonvascular epiphytes in a transition zone between tropical moist forest to tropical dry forest in the Choco biogeographic region of Valle del Cauca (Colombia)

\section{CUADRO 1}

Riqueza, abundancia y cobertura de epífitos en una zona de transición entre bosque húmedo tropical y bosque seco en el Chocó Biogeográfico del Valle del Cauca

\begin{tabular}{lccccc}
\multicolumn{1}{c}{ Grupo } & Non vascular Richness & Vascular Richness & Vascular Abundance & $\%$ CB & $\%$ CL \\
Zone 1 & 9 & 8 & 115 & 17.34 & 20.60 \\
Zone 2 & 10 & 8 & 151 & 32.69 & 15.02 \\
Zone 3 & 12 & 8 & 109 & 14.89 & 11.26 \\
Zone 4 & 7 & 6 & 149 & 51.06 & 12.66 \\
Zone 5 & 8 & 8 & 158 & 28.95 & 7.86 \\
Zone 6 & 10 & 8 & 161 & 9.74 & 24.31 \\
Closed microsite & 8 & 8 & 135 & 27.62 & 12.96 \\
Semi-open microsite & 9 & 7 & 152 & 17.47 & 23.77 \\
Open microsite & 18 & 7 & 139 & 14.10 & 12.22 \\
\hline
\end{tabular}

\% CB: Bryophytes coverage, \% CL: Lichens coverage.
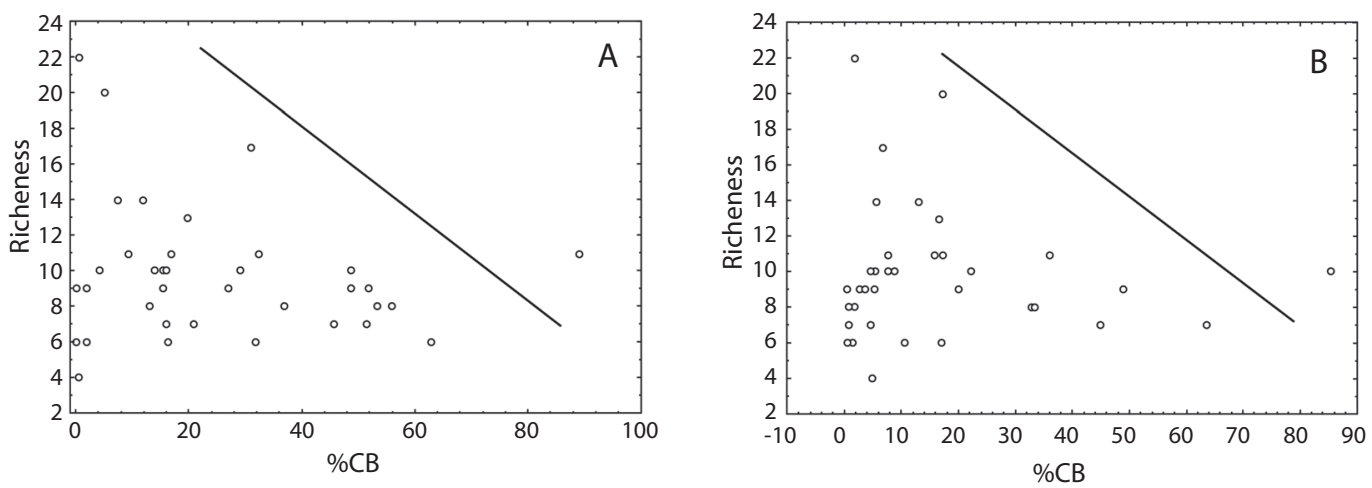

Fig. 2 (A). Edges test showing a pattern of decreasing richness with increasing of bryophyte coverage (\% CB) y (B) with increasing of lichen coverage (\% CL).

Fig. 2 (A). Prueba de bordes mostrando un patrón de disminución de la riqueza con el incremento de la cobertura de briofitos $(\% \mathrm{CB})$ y (B) el incremento de la cobertura de líquenes (\% CL).

microsite. As shown in the NMS analysis the trees within the open area (microsite) (3) were clustered, although one tree was growing at another microsite (Fig. 3A). The lichen assemblage in Zone 6 differed from the other areas (MRPP: $\mathrm{p}<0.005$ ), while the intermediate areas tended to be similar to each other. The results from the NMS for microsites for nonvascular epiphytes tended to be noisy (Fig. $3 \mathrm{~A}$ and Fig. 3B), although the clusters were more dispersed and less noticeable, but due to the results in the MRPP these clusters are statistically significant. The first NMS axis was related to the North-West coordinates $(r=0.49$, $r=0.49)$, while the second axis was the lichen coverage $(r=0.41)$. Thus, the noisy patterns and the discernible groups in NMS for nonvascular species, are better explained by the MRPP group comparison, which appears to be mainly related to their geographical location.

The NMS for vascular epiphytes also showed a slight cluster of trees according to 


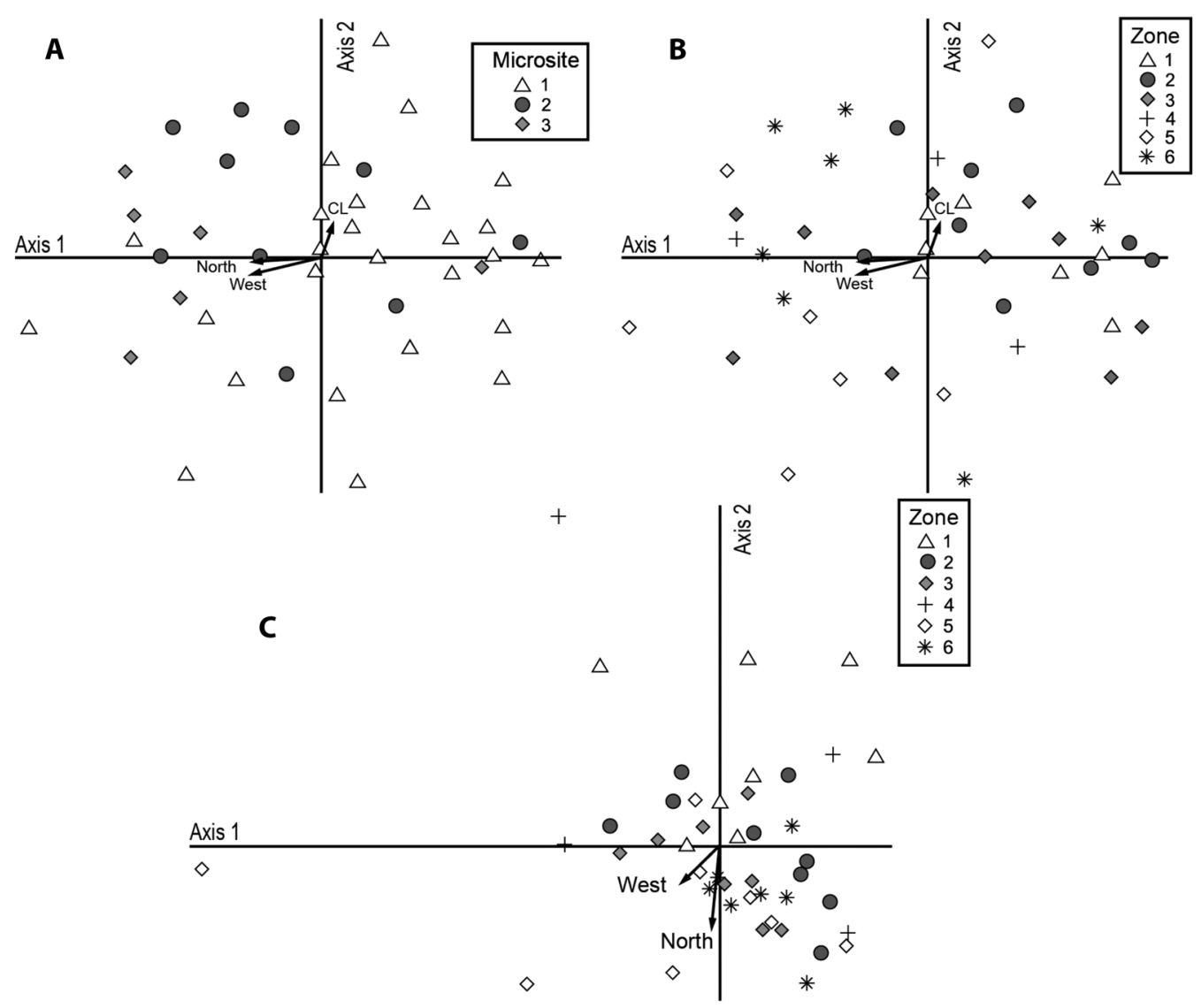

Fig. 3. (A) NMS for microsites for nonvascular epiphytes (1: closed, 2: Semi-open, 3: open). (B) NMS for nonvascular epiphytes sampled zones (Zone 1 is closest to the Tropical moist forest area and Zone 6 to the transition area (Tropical dry forest). (C) NMS for vascular epiphytes sampled zones (Zone 1 is closest to the Tropical moist forest area and Zone 6 to the transition area (Tropical dry forest).

Fig. 3. (A) NMS para micrositios para epífitos no vasculares (1: closed, 2: Semi-open, 3: open). (B) NMS para epífitos no vasculares muestreados por zonas (la zona 1 es la más cercana al área de bosque húmedo tropical y la zona 6 al área de bosque seco. (C)NMS para epífitos vasculares muestreados por zonas.

the sampling zone, but was not related to the microsite. The NMS axis 1 was related to the West $(r=0.34)$ coordinates, while axis 2 was related to both coordinates (North, $\mathrm{r}=$ 0.54 : West, $r=0.37$ ). This suggested that the composition of vascular epiphytes was primarily related to their geographical position (Fig. $3 \mathrm{C})$. Thus, the microsite was not important for the assembly of vascular plants, but the sampling zone was.

\section{DISCUSSION}

The Choco biogeographic region is a highly diverse area with high number of endemism, but poorly studied, that is why it released a high number of new records in this study. For this region, there are few lichens inventories that have recorded around 250 species between corticolous, terricolous and foliicolous species (Rangel, 2011; Soto-Medina, Lücking, 
\& Bolaños-Rojas, 2011; Mateus, Aguirre, \& Lucking, 2012).During this research, we found 90 non vascular epiphytes species, with 25 new lichens records for the country and 26 for Choco biogeographical region (Aguirre, 2008); this reflects the large gap in knowledge about this group. This species richness data is remarkably low compared with other areas (Cáceres et al., 2007, Soto-Medina et al., 2010), thus, this can be explained by the effect of the road which increases the environmental temperature and brings traffic flow pollutants, diminishing species richness (Brodo, 1966). We highlight the new record of the genus Thecaria a lichen of Graphidaceae, which has already been reported for Brazil, Costa Rica and Ecuador, and has wide distribution in the paleotropics (Archer, 2009). This genus seems to be mainly distributed in this region. On the other hand, we also report the genus Sticta (Lobariaceae) which becomes the record with the lowest altitude in the country (previous lowest record was ca. 450 m) (Moncada, Aguirre, \& Lücking, 2014). Also, this new record for the Lobariaceae family in the Choco biogeographic region, is due to the fog within the area as a result of the proximity to Dagua river, which had been proven that allows high diversity in cyanolichens (Holz \& Gradstein, 2005). Graphidaceae and Arthoniaceae presented the greatest diversity and the highest values of coverage, which is coherent with other studies in tropics, where these families are commonly dominant in low lands, due to their high species diversity which allows to cover a wide range of tropical environments (Rivas-Plata, Lücking, \& Lumbsch, 2008).

Regarding diversity patterns, it was found a greater species richness of nonvascular in open habitats than in the closed and semi-open ones. This is because lichens are photophilic, and only some tolerate high humidity and low irradiances (Lakatos, Rascher, \& Büdel, 2006). We found two different abundance patterns, one with a higher lichens abundance at semi-open sites, while the other shows higher abundance of bryophytes in closed sites. The increased coverage of lichens in semi-open sites, may result because in these microsites lichens do not compete with bryophytes, thus some species can develop large thalli. Bryophytes tend to prefer shadier sites, that is why it was found very abundant in the closed sites (Lakatos, Rascher \& Büdel, 2006). In addition, in the semi-open microsites mainly grew species of Arthoniaceae (Herpothallon, Arthonia) and Roccellaceae (Dichosporidium, Opegrapha), typical of shaded areas or understory, which tend to develop very large thalli. Moreover, in open places high input light allows many diasporas to prosper, so there is a high competition, which is reflected in the high number of species and the low abundance of lichens in this microsite over the other (Cáceres et al., 2007).

Regarding to the relationship between the nonvascular's richness vs. the abundance of bryophytes and lichens, it was found that trees with more coverage of bryophytes and lichens tended to have less richness of nonvascular species. This pattern is consistent with findings in other studies (Cáceres et al., 2007; Benitez et al., 2012). However, the scatter plot shows that there is a cloud of points that fill an area with right triangle pattern. This is because the sampling method used, produce a lot of data noise, requiring to use a different data analysis from traditional, one more relevant to macroecology (Rosabal et al., 2010). This noise can also be a cause of why the NMS patterns were not clear. Thus, although this sampling method is very good for diversity estimation, its constraint the data analysis, increasing its complexity.

When it comes to the assemblages of nonvascular epiphytes, we observed that trees showed a slightly grouping according to the microsites and zones. These patterns primarily responded to the geographic coordinates and lichens coverage. Thus, the variation in lichens coverage, as a result of differences in the input light to the trees, affected the assembly of nonvascular epiphytes in the 43 trees, as also did it the position along the road. The nonvascular epiphytes assembly is clearly defined by the light entry (Soto-Medina et al., 2011; Benítez, Prieto, González, \& Aragón, 2012). The effect of position along the road, is related to the effect of the transition zone between tropical 
moist forest and tropical dry forest; this is revealed by the presence in zone 5 and 6 of common species in dry forest (Coenogonium magdalenae Rivas Plata, Lücking \& Lizano, Porina imitatrix Müll. Arg.), while in zones 1 and 2 prevailed frequent species in tropical moist forest (Phyllopsora spp. Sarcographa spp.). This pattern was also observed in vascular epiphytes, whose patterns were related with the zones.

The sites that were classified as closed, mostly consisted of farms gardens with fruit crops (Quararibea cordata (Bonpl.) Vischer, Citrus limon (L.) Osbeck, Bactris gasipaes Kunth). In these places the richness of vascular epiphytes was higher due in large part to the contribution of individuals of the families Araceae, Gesneriaceae and Piperaceae, which tend to be more sensitive to disturbance and being in places with a closed canopy and more moisture (Gentry \& Dodson, 1987).

Most families with greater importance in terms of species richness and individuals abundance were considered as the most diverse, important and specialized families of epiphytes angiosperm in the Neotropics (Bromeliaceae and Orchidaceae) (Gentry \& Dodson, 1987; Arévalo \& Betancourt, 2004). This degree of specialization makes that such families represent the greatest diversity in habitats that do not normally have conducive features to the epiphytism (e.g. dry or low land forests). In addition, they have been registered with the biggest IVIF in other studies in Colombia along with Polypodiaceae (Alzate , Cardona, \& Callejas, 2001; Arévalo \& Betancourt, 2004). The importance of these families is consistent with the large representation they have in the overall composition of our vascular epiphytes records. Gesneriaceae, which was the third family in importance for this study, is considered as one of the families with more epiphytes species between dicots, among which are also known Piperaceae, Gesneriaceae, Melastomataceae, Ericaceae, Cactaceae, Clusiaceae and Marcgraviaceae families (Gentry \& Dodson, 1987).

Habitats with some degree of disturbance, usually have an affected diversity of vascular epiphytes species, restricted to the wind dispersed ones, due to being a favored dispersion mechanisms in disrupted ecosystems (Benzing, 1987). In this studied case, the most abundant species corresponded to families dispersed by wind mechanisms such as spores in Polypodiaceae, feathery seeds Bromeliaceae and dust like seeds in Orchidaceae (Benzing, 1987; Bartels \& Chen, 2012).

An agent that appears to regulate the nonvascular epiphytes assemblage in the area is the type of forest. The studied area ranged from the transition from the dry tropical forest to an area closer to the Pacific ocean considered as tropical moist forest, which handle a greater species diversity. Comparing with the dry forest, there is a greater density of individuals and species richness of vascular epiphytes in the moist forest, which represented up to one third of the recorded species (Gentry \& Dodson, 1987).

Finally, for this area, a greater species richness of epiphytes was expected than the one found during this study, which may be due to the degree of disturbance in the area. However, this disturbance appears not to affect the way in which the groups are distributed according to environmental factors, since it was possible to establish differences in richness, abundance and composition in the evaluated communities of epiphytes, between proposed zones and microsites. Additionally, these results are a sign of how little is known the biodiversity in the Choco biogeographic region, as we were able to record new species to the area in a place that has been disturbed for years.

Overall, the patterns of richness and diversity of epiphytes in forests of Choco biogeographic region, appear to be strongly related to the climatic conditions that characterize the forests of this area. In the case of this study, it was found that the richness and diversity of the communities of nonvascular epiphytes were affected by both the forest type (i.e. from wet to dry) and the microsite where the trees were, while communities of vascular epiphytes, were affected only by the forest type. Thus, it is possible to establish that a factor such as rainfall (which is the biggest climatic difference 
between tropical dry forests and tropical moist forest), appears to regulate the composition of vascular and nonvascular epiphytes in this area, and also the coverage plays an important role in variety of nonvascular epiphytes in this area.

\section{ACKNOWLEDGMENTS}

We would like to thank to the Consortium SSC and the Firm OM Ingeniería y Ambiente Ltda. for funding and allowing us to work in the area.

\section{RESUMEN}

Epífitas en una zona boscosa de transición en la región biogeográfica Chocó, Valle del Cauca, Colombia. Los bosques húmedos tropicales son ecosistemas que acumulan una alta biodiversidad y alto endemismo, principalmente en la ecorregión del Chocó biogeográfico. La vegetación en esta zona ha sido poco estudiada, sobre todo para el grupo de las epífitas. De esta forma, el objetivo de este trabajo fue evaluar la diversidad y composición de estas plantas (vasculares y no vasculares) en una zona de transición entre bosque húmedo tropical y bosque seco tropical en el Chocó biogeográfico. Se muestrearon 43 árboles con abundante cobertura de epífitas: las no vasculares fueron muestreadas hasta los $2 \mathrm{~m}$ de altura, mientras que las vasculares a lo largo de todo el forófito. Los datos se agruparon en seis zonas a lo largo de la vía, siendo la zona 1 la más cercana al Pacífico (bosque húmedo tropical) y la zona 6 la más cercana al enclave subxerofítico del río Dagua (bosque seco tropical); también se agruparon dependiendo de la exposición a la luz en tres micrositios: abiertos, semi abiertos y cerrados. Se recolectaron 485 ejemplares de epífitas no vasculares pertenecientes a 77 especies de líquenes, cinco de hepáticas y ocho de musgos, para un total de 90 especies. Por otro lado, se registraron 5987 individuos pertenecientes a 24 especies de epífitas vasculares, siendo la familia Bromeliaceae la más rica en especies (seis especies), seguida de Gesneriaceae, Orchidaceae y Polypodiaceae (cuatro especies). Se encontraron 25 nuevos registros de líquenes para Colombia, 26 para el Chocó biogeográfico, también 11 nuevos registros de epífitas vasculares para Chocó biogeográfico. La riqueza y diversidad de las comunidades de no vasculares fueron afectadas por la zona y el micrositio donde estaban los árboles, mientras que en las comunidades de vasculares, fueron afectadas por la zona a lo largo de la carretera.

Palabras clave: Chocó biogeográfico, composición, diversidad, factores microclimáticos, micrositios, riqueza, epífitas vasculares y no vasculares.

\section{REFERENCES}

Aguirre-C., J. (2008). Catálogo de los líquenes de Colombia. In J. O. Rangel (Eds.). Colombia diversidad biótica VI: Riqueza y diversidad de los musgos y líquenes en Colombia (pp. 401-547). Bogotá: Universidad Nacional de Colombia.

Alzate, F., Cardona, F., \& Callejas, R. (2001). Diversidad y composición de epífitas vasculares en robledales de Antioquia (Colombia). Actualidades Biológicas, 23(74), 25-31.

Archer, A. W. (2009). Graphidaceae. Flora of Australia, 57, 84-194.

Arévalo, R. \& Betancour, J. (2004). Diversidad de epífitas vasculares en cuatro bosques del sector suroriental de la serranía de Chiribiquete, Guayana Colombiana. Caldasia, 26(2), 359-380.

Bartels, S. F., \& Chen, H. Y. H. (2012). Mechanisms regulating epiphytic plant diversity. Critical Reviews in Plant Sciences, 31(5), 391-400.

Benzing, D. H. (1987). Vascular epiphytism: Taxonomic participation and adaptive diversity. Annals of the Missouri Botanical Garden, 74(2), 183-204.

Benítez, A., Prieto, M., González, Y., \& Aragón, G. (2012). Effects of tropical montane forest disturbance on epiphytic macrolichens. Science of the Total Environment, 441, 169-175.

Brodo, I. M. (1966). Lichen growth and cities: A study on Long Island, New York. The Bryologist, 69, 427-449.

Cáceres, M. E. S., Lücking, R., \& Rambold, G. (2007). Phorophyte specificity and environmental parameters versus stochasticity as determinants for species composition of corticolous crustose lichen communities in the Atlantic moist forest of northeastern Brazil. Mycological Progress, 6(3), 117-136.

Foster, P. (2001). The potential negative impacts of global climate change on tropical montane cloud forests. Earth-Science Reviews, 55, 73-106.

Gentry, A. H., \& Dodson, C. H. (1987). Diversity and biogeography of Neotropical vascular epiphytes. Annals of the Missouri Botanical Garden, 47(2), 205-233.

Gotelli, N. J., \& Entsminger, G. L. (2004). EcoSim: Null models software for ecology. Version 7. Burlington: Acquired Intelligence Inc. \& Kesey-Bear. Jericho, VT 05465, http://www.uvm.edu/ ngotelli/EcoSim/ EcoSim.html

Holdridge, L. R. (1967). Life zone ecology. San José, Costa Rica: Tropical Science Center.

Holz, I., \& Gradstein, S. R. (2005). Cryptogamic epiphytes in primary and recovering upper montane oak forests of Costa Rica-species richness, community composition and ecology. Plant Ecology, 178, 89-109. 
IDEAM. (2014). Estación Meteorológica Cisneros. Promedios climatológicos 1981 a 2010 (Last view: September, 2014 http://institucional.ideam.gov.co/descargas ?com=institucional\&name $=$ pubFile $15803 \&$ downloa dname $=$ Promedios $\% 2081-10 . x 1 s x$ )

Lakatos, M., Rascher, U., \& Büdel, B. (2006). Functional characteristics of corticolous lichens in the understory of a tropical lowland moist forest. New Phytologist, 172, 679-695.

Mateus, N., Aguirre, J., \& Lucking, R. (2012). Contribuciones a la biota liquénica folícola del Chocó (Colombia). Caldasia, 34(1), 25-32.

McCune, B. (1990) Rapid Estimation of Abundance of Epiphytes on Branches. The Bryologist, 93(1), 39-43.

McCune, B., \& Mefford, M. J. (1999). PC-ORD Multivariate analysis of ecological data, Version 4.0. Gleneden Beach: MjM Software. Retrieved from http:// www.pcord.com/pcordwin.htm.

McCune, B., Grace, J. B., \& Urban, D. L. (2002). Analysis of ecological communities. Oregon: MjM Software, Gleneden Beach.

Moncada, B., Aguirre-C., J., \& Lücking, R. (2014) Ecogeografía del género Sticta (Ascomycota liquenizados: Lobariaceae) en Colombia. Revista de Biología Tropical, 62(2), 257-272.

Mori, S. A., Boom, B., Carvalho, A. M., \& dos Santos, T. S. (1983). Ecological importance of Myrtaceae in an eastern Brazilian wet forest. Biotropica, 15, 68-70.
Rangel, J. O. (2011). Colombia diversidad biótica XI, patrones de la estructura y de la riqueza de la vegetación en Colombia. Bogotá: Instituto de Ciencias Naturales.

Rivas- Plata, E., Lücking, R., \& Lumbsch, H. T. (2008). When family matters: an analysis of Thelotremataceae (lichenized Ascomycota: Ostropales) as bioindicators of ecological continuity in tropical forests. Biodiversity and Conservation, 17, 1319-1351.

Ruiz-Domínguez, C. \& Cabrera-Rodríguez, I. (2012). Colecciones florísticas realizadas en la provincia del Chocó biogeográfico colombiano. Biota Colombiana, 13(1), 3-17.

Rosabal, D., Burgaz, A. R., \& de la Masa, R. (2010). Diversity and distribution of epiphytic macrolichens on tree trunks in two slopes of the montane moist forest of Gran Piedra, Santiago de Cuba. Bryologist, 113, 313-321.

Soto-Medina, E., Lücking, R., \& Bolaños-Rojas, A. (2011). Especificidad de forófito y preferencias microambientales de los líquenes cortícolas en cinco especies de forófitos en el bosque premontano de la finca Zíngara (Cali, Colombia). Revista de Biología Tropical, 59(4), 843-856.

Statsoft. (2005). STATISTICA (data analysis software system), Version 7.1. Tulsa: Statsoft, Inc. Retrieved from http://www.statsoft.com.

Wolf, J. H. D. (1994). Factors controlling the distribution of vascular and nonvascular epiphytes in the northern Andes. Vegetatio, 112, 15-28. 


\section{APPENDIX}

TABLE A

Records of nonvascular epiphytes

\begin{tabular}{|c|c|}
\hline Species & Family \\
\hline Anthracothecium prasinum (Eschw.) R. C. Harris & Pyrenulaceae \\
\hline Astrothelium variolosum (Ach.) Müll.Arg. & Trypetheliaceae \\
\hline Bacidina varia $\mathrm{S}$. Ekman & Ramalinaceae \\
\hline Calopadia editae Vezda ex Chaves \& Lücking & Pilocarpaceae \\
\hline Chrysothrix candelaris (L.) J.R. Laundon & Chrysothricaceae \\
\hline Coenogonium pineti (Ach.) Lücking \& Lumbsch. & Coenogoniaceae \\
\hline Dictyonema irrigatum (Berk. \& M. A. Curtis) Lücking & Hygrophoraceae \\
\hline Dictyonema obscuratum Lücking, Spielmann \& Marcelli & Hygrophoraceae \\
\hline Diorygma circumfusum (Stirt.) Kalb, Staiger \& Elix. & Graphidaceae \\
\hline Diorygma rufopruinosum (A.W.Archer) Kalb, Staiger \& Elix. & Graphidaceae \\
\hline Gassicurtia catasema (Tuck.) Marbach & Caliciaceae \\
\hline Graphis ferruginea Vain. & Graphidaceae \\
\hline Graphis glaucescens Fée. & Graphidaceae \\
\hline Graphis schroederi Zahlbr. & Graphidaceae \\
\hline Herpothallon albidum (Fée) Aptroot, Lücking \& G. Thor. & Arthoniaceae \\
\hline Herpothallon confluenticum Aptroot \& Lücking & Arthoniaceae \\
\hline Herpothallon japonicum (Zahlbr.) G. Thor & Arthoniaceae \\
\hline Laurera cf. megasperma (Mont.) Riddle & Trypetheliaceae \\
\hline Laurera phaeomelodes (Müll. Arg.) Zahlbr. & Trypetheliaceae \\
\hline Bactrospora flavopruinosa F. Berger \& Aptroot & Roccellaceae \\
\hline Opegrapha subdimidiata Ertz & Roccellaceae \\
\hline Opegrapha viridipruinosa B.J. Coppins \& R. Yahr & Roccellaceae \\
\hline Phaeographis kalbii Staiger & Graphidaceae \\
\hline Phyllopsora buetneri (Müll.Arg.) Zahlbr. & Ramalinaceae \\
\hline Phyllopsora chlorophaea (Müll. Arg.) Zahlbr. & Ramalinaceae \\
\hline Phyllopsora isidiotyla (Vainio) Riddle. & Ramalinaceae \\
\hline Phyllopsora labriformis Timdal. & Ramalinaceae \\
\hline Physcia atrostiata Moberg & Physciaceae \\
\hline Pyrenula laii Aptroot & Pyrenulaceae \\
\hline Pyrenula quassiaecola Fée & Pyrenulaceae \\
\hline Pyxine sorediata (Ach.) Mont. & Physciaceae \\
\hline Sticta $\mathrm{sp}$ & Lobariaceae \\
\hline Thecaria montagnei (Bosch) Staiger & Graphidaceae \\
\hline Trypethelium nitidiusculum (Nyl.) R.C. Harris & Trypetheliaceae \\
\hline
\end{tabular}


TABLE B

Records of epiphytes vascular plants

\begin{tabular}{llc}
\multicolumn{1}{c}{ Especie } & Familia & Grupo \\
*Anthurium friedrichsthalii Schott & Araceae & Angiosperm \\
*Anthurium scandens (Aubl.) Engl. & Araceae & Angiosperm \\
**Asplenium sulcatum Lam. & Aspleniaceae & Fern \\
Aechmea angustifolia Poepp. \& Endl. & Bromeliaceae & Angiosperm \\
*Catopsis nutans (Sw.) Griseb. & Bromeliaceae & Angiosperm \\
Guzmania rhonhofiana Harms & Bromeliaceae & Angiosperm \\
Tillandsia bulbosa Hook. & Bromeliaceae & Angiosperm \\
Tillandsia usneoides (L.) L. & Bromeliaceae & Angiosperm \\
Vriesea gladioliflora (H. Wendl.) Antoine & Bromeliaceae & Angiosperm \\
Codonanthe crassifolia (H. Focke) C.V. Morton & Gesneriaceae & Angiosperm \\
*Columnea angustata (Wiehler) L.E. Skog & Gesneriaceae & Angiosperm \\
*Columnea spathulata Mansf. & Gesneriaceae & Angiosperm \\
Drymonia sp. & Gesneriaceae & Angiosperm \\
*Dimerandra emarginata (G. Mey.) Hoehne & Orchidaceae & Angiosperm \\
Epidendrum lacustre Lindl. & Orchidaceae & Angiosperm \\
*Epidendrum rigidum Jacq. & Orchidaceae & Angiosperm \\
Rodriguezia lanceolata Ruiz \& Pav. & Orchidaceae & Angiosperm \\
*Peperomia obtusifolia (L.) A. Dietr. & Piperaceae & Angiosperm \\
Peperomia rotundifolia (L.) Kunth & Piperaceae & Angiosperm \\
*Campyloneurum phyllitidis (L.) C. Presl & Polypodiaceae & Fern \\
Microgramma reptans (Cav.) A.R. Sm. & Polypodiaceae & Fern \\
Pleopeltis bombycina (Maxon) A.R. Sm. & Polypodiaceae & Fern \\
Serpocaulon triseriale (Sw.) A.R. Sm. & Polypodiaceae & Fern \\
Radiovittaria gardneriana (Fée) E.H. Crane & Pteridaceae & Fern \\
\hline
\end{tabular}

* New Record Chocó Biogeographic region, Valle. **New Record for Colombia. 